\title{
A community survey of respiratory disease among East Indian and African adults in Guyana
}

\author{
G. J. MILLER and M.T.ASHCROFT \\ Medical Research Council Epidemiology Unit, University of the West Indies, Kingston, Jamaica
}

\begin{abstract}
The belief that chronic bronchitis is more prevalent among Indians than Africans in the Caribbean area was investigated by a community survey in Guyana. Respiratory symptoms were assessed by a standard questionnaire, ventilatory capacities were measured, and chest radiographs were taken of some 800 African and Indian men and women aged 35 to 54 years living in adjacent and similar communities. Histories of morning cough, chronic cough, morning phlegm, and chronic phlegm (chronic bronchitis) were more common in Indians than Africans. Although these respiratory symptoms were much more common in smokers than non-smokers, the higher prevalence rates in Indians could not be explained by smoking habits which were similar in the two races. Chronic bronchitis occurred in $17.3 \%$ of Indian and $2.4 \%$ of African male smokers and in $6.1 \%$ and $2.2 \%$ of Indian and African female non-smokers respectively. Judging by the history, lung function, and clinical signs, chronic bronchitis was more severe in Indians than Africans. The condition was more common among field labourers on sugar estates but, although the majority of field labourers were Indian, this occupational difference only partially explained the difference in prevalence between Indians and Africans. Indians, for reasons unknown, appear to have a greater susceptibility than Africans to chronic bronchitis.
\end{abstract}

For many years physicians in the Caribbean have been impressed by a seemingly greater prevalence of various respiratory diseases in the East Indian ${ }^{1}$ than the African subject. This impression has been formed not only in Guyana and Trinidad, which have the largest number of Indians, but also in Jamaica. Lobar pneumonia (Daniels, 1894), pulmonary eosinophilia (Herlinger, 1963), diffuse pulmonary fibrosis (Miller, Beadnell, and Ashcroft, 1968), and chronic bronchitis and emphysema (Miller and Hayes, 1968) have all been found to be more common among Indians.

The demography of Guyana makes it a suitable Caribbean territory for a population survey of chronic respiratory diseases among African and Indian subjects since here they live side by side, sharing a similar socio-economic background although remaining ethnically distinct.

\section{POPULATION AND METHODS}

Guyana, formerly British Guiana, lies on the northeastern corner of the South American continent between $8^{\circ} 40^{\prime} \mathrm{N} 3^{\circ} 30^{\prime} \mathrm{S}$ and $50^{\circ}$ to $68^{\circ} 30^{\prime} \mathrm{W}$. Over $90 \%$

In the Caribbean, especially in Guyana, the descendants of immigrants from India are called East Indians to distinguish them from the Amerindian and West Indian in general. Elsewhere in this paper the prefix 'East' will be omitted of its population occupy the narrow coastal plain that borders the Atlantic ocean. The coastland has a tropical rainy climate and relative humidity averages about $82 \%$ (range $70-94 \%$ ). The average annual rainfall is 95 in (2.4 $\mathrm{m})$ and is described as occurring in two rainy seasons from May to July and from December to January; in fact rainfall is less predictable and 'dry' seasons can be wet. The temperature is fairly constant throughout the year, the mean daily average being $81^{\circ} \mathrm{F}$ (range $75-88^{\circ} \mathrm{F}$ ); $27^{\circ} \mathrm{C}$ (range $24-31^{\circ} \mathrm{C}$ ).

A private census was made of two villages, Buxton and Annandale, situated on the coast 12 miles outside the capital city of Georgetown. The people of Buxton are African, descendants of people brought from West Africa before the abolition of the slave trade in 1807 . Those of Annandale are Indians, whose forebears came as indentured immigrants from India between 1845 and 1917. There has been little intermixing between the two races although some of the Africans, but not the Indians, have a small amount of European ancestry. The two villages lie adjacent to each other in a uniform rural environment, facing the Atlantic and bounded elsewhere by sugar estates. Although the climate is tropical, the disease pattern is now more similar to that of countries in temperate zones. Malaria was eradicated from the area in which the survey took place in 1949 and anaemia due to hookworm infection is now rarely seen. Filariasis, due to Wuchereria bancrofti, remains common. 
All persons aged 35 to 54 years were requested to attend the local hospital. Date of birth was confirmed in most cases by inspection of the birth certificate. Attendance from the two villages was arranged on alternate days so that any variations in technique were evenly distributed. Each subject answered a basic questionnaire for occupation and for past medical history and then answered the Medical Research Council's questionnaire for respiratory symptoms $(1966)^{2}$ to which the following modifications had been made for local application:

1. The phrase 'in the winter' was deleted from questions $1,3,6$, and 8 and no substitution was made as there is no recognized seasonal variation in respiratory symptoms in Guyana.

2 . The sections dealing with the relationships between weather and respiratory symptoms and with nasal catarrh were omitted.

3. The section on tobacco smoking was extended to cover the consumption of local tobacco.

4. The section on dusty occupations was altered to cover the sugar and rice industries, mining, the bauxite industry, and asbestos.

The respiratory and cardiovascular systems were examined clinically and an ECG was recorded. The cardiovascular results have been reported by Ashcroft, Beadnell, Bell, and Miller (1970). The forced expiratory volume in one second $\left(F E V_{1}\right)$ and forced vital capacity (FVC) were measured with a dry spirometer (Collins, McDermott, and McDermott, 1964). Restrictive garments were removed and subjects were seated for the test. Nose clips were not used. The values for each subject were obtained from the mean of three technically satisfactory measurements after two practice attempts, and were expressed in litres at body temperature and pressure saturated with water vapour (1.BTPS). The response to the questionnaire and the results of spirometry were recorded by one investigator (G.J.M.). Regression relationships based on height and age describing the FEV and FVC of healthy subjects of the two ethnic groups have been reported by Miller, Ashcroft, Swan, and Deadnell (1971).

One observer (M.T.A.) weighed all subjects on a balance scale and recorded their height with a stadiometer. The anthropometric data have been reported by Ashcroft, Beadnell, Miller, and Bell (1969). A postero-anterior radiograph of the chest in full inspiration was taken with a tube distance of $6 \mathrm{ft}(1.8 \mathrm{~m})$ using a standard apparatus.

The census showed 1,060 persons aged 35 to 54 years in the two villages, and $860(82 \cdot 8 \%)$ persons attended for interview. Of these, 17 subjects, although interviewed, were not included in the analysis because of pregnancy or because they were not of predominantly African or Indian origin. The smoking habits of the remaining 843 (165 African men, 214 Indian men, 242 African women, and 222 Indian women) are shown in Table I. Pipe smokers (16), female cigarette smokers (19), and ex-smokers (58) were not included

${ }^{2}$ Obtainable from W. J. Holman Ltd., Dawlish, Devon, England in the analysis of respiratory symptoms because they were few, and the majority of ex-smokers had smoked little. Data from 141 African men, 183 Indian men, 230 African women, and 196 Indian women were used for the analysis of respiratory symptoms; all were either smokers at the time of examination or had never smoked.

The division of cigarette smokers into four categories according to their tobacco consumption resulted in numbers of subjects which were too small for statistical analysis and therefore all smokers were considered as a single group. Persons with the two severer grades ( 3 and 4 ) of breathlessness, as defined by the questionnaire, were also too few and therefore all grades were pooled. The term 'chronic' was defined as 'occurring on most days for at least three consecutive months', and 'chronic bronchitis' implied expectoration of at least this duration (Medical Research Council's Committee on the Aetiology of Chronic Bronchitis, 1965)

Predicted normal values for the FEV 1 and FVC of subjects with chronic bronchitis were calculated from regression equations describing the $\mathrm{FEV}_{1}$ and FVC of healthy Guyanese subjects (Miller et al., in preparation). The differences between the means of measured values and predicted values for each group of chronic bronchitic subjects were tested by bivariate covariance analysis.

For a statistical comparison of prevalence rates. between various groups, Fisher's exact test for 2 by 2 tables was used. Differences were considered significant if the likelihood of occurrence by chance was less than $5 \%(P<0.05)$.

\section{RESULTS}

Table I presents the smoking habits of the population surveyed and shows that the prevalence of cigarette smoking and tobacco consumption among African and Indian men was similar, $51.5 \%$ of Africans smoking cigarettes compared to $45.8 \%$ of Indians. Only $6.8 \%$ and $1.7 \%$ of Indian and African women respectively smoked cigarettes. Heavy smoking was uncommon, 10.9\% of African men and $10.7 \%$ of Indian men smoked more than $15 \mathrm{~g}$ of cigarette tobacco per day.

The prevalence rates of morning cough, chronic cough, morning phlegm, and chronic phlegm (chronic bronchitis) in African and Indian male smokers and non-smokers are given in Table II, and corresponding data for Indian and African female non-smokers in Table III. As noted previously, ex-smokers, pipe smokers, and female cigarette smokers have been excluded. The results of significance tests for the differences in prevalence of these symptoms between various groups are shown in Table IV. One of the most striking features was that cough and phlegm, both morning and chronic in type, were more prevalent 
T A B L E I

SMOKING HABITS OF GUYANESE MEN AND WOMEN

\begin{tabular}{|c|c|c|c|c|c|c|c|c|}
\hline \multirow{3}{*}{ Group } & \multicolumn{4}{|c|}{ Men } & \multicolumn{4}{|c|}{ Women } \\
\hline & \multicolumn{2}{|c|}{ African (165) } & \multicolumn{2}{|c|}{ Indian (214) } & \multicolumn{2}{|c|}{ African (242) } & \multicolumn{2}{|c|}{ Indian (222) } \\
\hline & No. & $\%$ of Total & No. & $\%$ of Total & No. & $\%$ of Total & No. & $\%$ of Total \\
\hline Ex-smokers & 18 & $10 \cdot 9$ & 27 & $12 \cdot 6$ & 8 & $3 \cdot 3$ & 5 & $2 \cdot 3$ \\
\hline Pipe smokers & 6 & 3.6 & 4 & 1.9 & 0 & 0 & 6 & $2 \cdot 7$ \\
\hline $\begin{array}{c}\text { Cigarette smokers: } \\
1-4 \mathrm{~g} / \text { day } \\
5-14 \mathrm{~g} / \text { day } \\
15-24 \mathrm{~g} / \text { day } \\
25+\mathrm{g} / \text { day } \\
\text { Total cigarette smokers }\end{array}$ & $\begin{array}{r}15 \\
52 \\
13 \\
5 \\
85\end{array}$ & $\begin{array}{r}9 \cdot 1 \\
31 \cdot 5 \\
7 \cdot 9 \\
3 \cdot 0 \\
51 \cdot 5\end{array}$ & $\begin{array}{r}14 \\
61 \\
20 \\
3 \\
98\end{array}$ & $\begin{array}{r}6 \cdot 5 \\
28 \cdot 5 \\
9 \cdot 3 \\
1 \cdot 4 \\
45 \cdot 8\end{array}$ & $\begin{array}{l}4 \\
0 \\
0 \\
0 \\
4\end{array}$ & $\begin{array}{l}1 \cdot 7 \\
0 \\
0 \\
0 \\
1 \cdot 7\end{array}$ & $\begin{array}{r}10 \\
5 \\
0 \\
0 \\
15\end{array}$ & $\begin{array}{l}4 \cdot 5 \\
2 \cdot 3 \\
0 \\
0 \\
6 \cdot 8\end{array}$ \\
\hline $\begin{array}{l}\text { Non-smokers } \\
\text { Subjects in } \\
\text { respiratory analysis }{ }^{1}\end{array}$ & $\begin{array}{r}56 \\
141\end{array}$ & $\begin{array}{l}33 \cdot 9 \\
85 \cdot 5\end{array}$ & $\begin{array}{r}85 \\
183\end{array}$ & $\begin{array}{l}39 \cdot 7 \\
85 \cdot 5\end{array}$ & $\begin{array}{l}230 \\
230\end{array}$ & $\begin{array}{l}95 \cdot 0 \\
95 \cdot 0\end{array}$ & $\begin{array}{l}196 \\
196\end{array}$ & $\begin{array}{l}88 \cdot 3 \\
88 \cdot 3\end{array}$ \\
\hline
\end{tabular}

1 Ex-smokers, pipe smokers, and all female smokers excluded

T A B LE I I

PREVALENCE OF RESPIRATORY SYMPTOMS IN GUYANESE MALE SMOKERS AND NON-SMOKERS

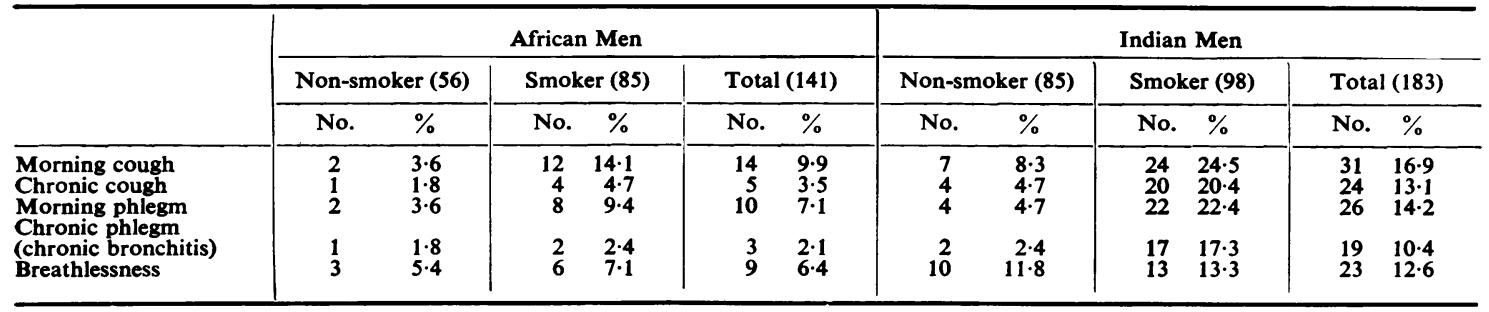

T A B L E I I I

PREVALENCE OF RESPIRATORY SYMPTOMS IN GUYANESE FEMALE NON-SMOKERS

\begin{tabular}{|c|c|c|c|c|}
\hline & \multicolumn{2}{|c|}{ African Women (230) } & \multicolumn{2}{|c|}{ Indian Women (196) } \\
\hline & No. & $\%$ & No. & $\%$ \\
\hline $\begin{array}{l}\text { Morning cough } \\
\text { Chronic cough } \\
\text { Morning phlegm } \\
\text { Chronic phlegm } \\
\text { (chronic bronchitis) } \\
\text { Breathlessness }\end{array}$ & $\begin{array}{r}9 \\
8 \\
8 \\
5 \\
71\end{array}$ & $\begin{array}{r}3 \cdot 9 \\
3 \cdot 5 \\
3 \cdot 5 \\
2 \cdot 2 \\
30 \cdot 9\end{array}$ & $\begin{array}{l}21 \\
15 \\
20 \\
12 \\
60\end{array}$ & $\begin{array}{r}10 \cdot 7 \\
7 \cdot 7 \\
10 \cdot 2 \\
6 \cdot 1 \\
30 \cdot 6\end{array}$ \\
\hline
\end{tabular}

in smokers than non-smokers in men of both races but particularly in Indians, in whom the differences were statistically significant. Indian smokers had significantly more morning phlegm, chronic cough, and chronic bronchitis $(17 \cdot 3 \%$ compared with $2.4 \%$ ) than African smokers. In both sexes, Indian non-smokers had slightly higher prevalence rates of cough and phlegm than African non-smokers, but these differences were not statistically significant, except for morning cough and phlegm in women. Chronic bronchitis occurred in $6.1 \%$ and $2.2 \%$ of Indian and African female non-smokers respectively. No significant differences occurred in the prevalence of these symptoms between non-smoking men and nonsmoking women.

Breathlessness was far more common among women than men in both ethnic groups (Tables II to IV). Although more Indian than African men, and smokers than non-smokers, had breathlessness, the differences were not significant. The prevalence of breathlessness was similar in Indian and African women. In the majority of men and women breathlessness was of grade II severity only, and in women was related to the high prevalence of obesity (Ashcroft et al., 1969).

Occasional or frequent wheezing was mentioned by $74(22.8 \%)$ men and $88(20.7 \%)$ women, almost always in association with upper respiratory tract infections. Only 6 men and 4 women gave a history of frequent wheezing. No significant differences in the prevalence of this symptom were found between sexes, ethnic groups of smokers and non-smokers.

A history of asthma was given by $2(1.4 \%)$ African men, 9 (4.9\%) Indian men, 7 (3.0\%) African women, and $5(2 \cdot 6 \%)$ Indian women, 
T A B L E I V

STATISTICAL SIGNIFICANCE OF DIFFERENCES IN PREVALENCE OF RESPIRATORY SYMPTOMS IN VARIOUS GROUPS OF GUYANESE SUBJECTS

\begin{tabular}{|c|c|c|c|c|c|c|}
\hline \multirow{2}{*}{\multicolumn{2}{|c|}{ Comparisons $^{2}$}} & $\underset{\text { Cough }}{\text { Morning }}$ & $\begin{array}{l}\text { Chronic } \\
\text { Cough }\end{array}$ & $\begin{array}{l}\text { Morning } \\
\text { Phlegm }\end{array}$ & $\begin{array}{l}\text { Chronic } \\
\text { Phlegm }\end{array}$ & Breathlessness \\
\hline & & $\mathbf{P}$ & $\mathbf{P}$ & $\mathbf{P}$ & $\mathbf{P}$ & $\mathbf{P}$ \\
\hline $\begin{array}{l}\text { Men: } \\
\text { Indian non-smokers } \\
\text { Indian smokers } \\
\text { All Indians } \\
\text { African smokers } \\
\text { Indian smokers } \\
\text { All smokers }\end{array}$ & $\begin{array}{l}\text { v. African non-smokers } \\
\text { v. African smokers } \\
\text { v. All Africans } \\
\text { v. African non-smokers } \\
\text { v. Indian non-smokers } \\
\text { v. All non-smokers }\end{array}$ & $\begin{array}{l}\text { N.S. } \\
\text { N.S. } \\
\text { N.S. } \\
\text { N.S. } \\
<\mathbf{0 . 0 1} \\
<\mathbf{0 . 0 0 1}\end{array}$ & $\begin{array}{l}\text { N.S. } \\
<0.001 \\
<0.05 \\
\text { N.S. } \\
<0.01 \\
<0.01\end{array}$ & $\begin{array}{l}\text { N.S. } \\
<0.05 \\
\sim 0.05 \\
\text { N.S. } \\
<0.001 \\
<0.001\end{array}$ & $\begin{array}{l}\text { N.S. } \\
<0.01 \\
<0.01 \\
\text { N.S. } \\
<0.01 \\
<0.01\end{array}$ & $\begin{array}{l}\text { N.S. } \\
\text { N.S. } \\
\text { N.S. } \\
\text { N.S. } \\
\text { N.S. } \\
\text { N.S. }\end{array}$ \\
\hline $\begin{array}{l}\text { Women: } \\
\text { Indian non-smokers }\end{array}$ & v. African non-smokers & $<0.01$ & N.S. & $<0.01$ & N.S. & N.S. \\
\hline All female non-smokers & v. All male non-smokers & N.S. & N.S. & N.S. & N.S. & $<0.001$ \\
\hline
\end{tabular}

1 In each instance the group with the higher prevalence rate appears first.

N.S. = not statistically significant.

T A BLE V

PREVALENCE OF A HISTORY OF WHEEZING IN GUYANESE SUBJECTS WITH AND WITHOUT CHRONIC BRONCHITIS

\begin{tabular}{|c|c|c|c|c|c|c|c|c|c|c|c|c|}
\hline & \multicolumn{6}{|c|}{ African } & \multicolumn{6}{|c|}{ Indian } \\
\hline & \multicolumn{3}{|c|}{ Men } & \multicolumn{3}{|c|}{ Women } & \multicolumn{3}{|c|}{ Men } & \multicolumn{3}{|c|}{ Women } \\
\hline & \multirow{2}{*}{$\begin{array}{l}\text { No. of } \\
\text { Subjects }\end{array}$} & \multicolumn{2}{|c|}{$\begin{array}{l}\text { History of } \\
\text { Wheezing }\end{array}$} & \multirow{2}{*}{$\begin{array}{l}\text { No. of } \\
\text { Subjects }\end{array}$} & \multicolumn{2}{|c|}{$\begin{array}{l}\text { History of } \\
\text { Wheezing }\end{array}$} & \multirow{2}{*}{$\begin{array}{l}\text { No. of } \\
\text { Subjects }\end{array}$} & \multicolumn{2}{|c|}{$\begin{array}{l}\text { History of } \\
\text { Wheezing }\end{array}$} & \multirow{2}{*}{$\begin{array}{l}\text { No. of } \\
\text { Subjects }\end{array}$} & \multicolumn{2}{|c|}{$\begin{array}{l}\text { History of } \\
\text { Wheezing }\end{array}$} \\
\hline & & No. & $\%$ & & No. & $\%$ & & No. & $\%$ & & No. & $\%$ \\
\hline $\begin{array}{l}\text { Chronic bronchitics } \\
\text { Non-bronchitics } \\
\text { Total }\end{array}$ & $\begin{array}{r}3 \\
138 \\
141\end{array}$ & $\begin{array}{r}2 \\
27 \\
29\end{array}$ & $\begin{array}{l}66 \cdot 7 \\
19 \cdot 6 \\
20 \cdot 6\end{array}$ & $\begin{array}{r}5 \\
225 \\
230\end{array}$ & $\begin{array}{r}4 \\
45 \\
49\end{array}$ & $\begin{array}{l}80 \cdot 0 \\
20 \cdot 1 \\
21 \cdot 3\end{array}$ & $\begin{array}{r}19 \\
164 \\
183\end{array}$ & $\begin{array}{l}13 \\
32 \\
45\end{array}$ & $\begin{array}{l}68 \cdot 4 \\
19 \cdot 5 \\
24 \cdot 6\end{array}$ & $\begin{array}{l}12 \\
184 \\
196\end{array}$ & $\begin{array}{l}10 \\
29 \\
39\end{array}$ & $\begin{array}{l}83.3 \\
15.8 \\
19.9\end{array}$ \\
\hline $\mathbf{P}$ & \multicolumn{3}{|c|}{ N.S. } & \multicolumn{3}{|c|}{$\sim 0.01$} & \multicolumn{3}{|c|}{$<0.001$} & \multicolumn{3}{|c|}{$<0.001$} \\
\hline
\end{tabular}

differences which were not statistically significant. The overall prevalence of asthma was $3 \cdot 1 \%$. The majority of subjects with a history of asthma stated that they had some degree of breathlessness between attacks.

A history of pneumonia was given by 27 African men (19.1\%) and 17 (9.3\%) Indian men, a difference which was significant $(P \sim 0.01)$. Among women, a history of pneumonia was given by $9.6 \%$ of Africans and $9.2 \%$ of Indians.

Wheezing, breathlessness, and a history of pneumonia or asthma were all more common among chronic bronchitic subjects than nonbronchitics. Table $\mathrm{V}$ shows that subjects of both sexes with chronic bronchitis had more wheezing than non-bronchitics. Of the 39 bronchitics, $18(46.2 \%)$ had breathlessness compared with 144 $(20 \cdot 3 \%)$ of the 711 non-bronchitics $(P<0.001)$. Asthma and pneumonia were mentioned respectively by $4(10.3 \%)$ and $9(23.1 \%)$ chronic bronchitics compared with $19(2.7 \%)$ and 77 (10.8\%) non-bronchitics, differences which did not achieve statistical significance.

The FEV $_{1}$ and FVC of subjects with chronic bronchitis are given in Table VI. The $\mathrm{FEV}_{1}$ was significantly reduced in Indian but not in African men and women with bronchitis. Indian male bronchitics were particularly affected, having a mean $\mathrm{FEV}_{1} / \mathrm{FVC} \%$ of $67.2 \%$ compared with a normal value of $80.2 \%$ predicted from their height and age. FVC was not significantly reduced in any group with bronchitis.

Six $(31.6 \%)$ Indian male bronchitics, but none of the other bronchitics, had wheezing in the chest on auscultation, and one of these six had finger clubbing. Six Indian men and one African man had been admitted to hospital in the past for acute exacerbations of their bronchitis.

Five radiographs showed abnormal lung fields, apart from calcified tuberculous primary foci. One Indian woman had active tuberculosis and one Indian woman and one African woman showed healed tuberculosis. The appearances of basal bronchiectasis were seen in the film of an Indian man and of histoplasmosis in that of another Indian man.

Occupations were divided into three crude categories. Class I involved heavy physical work and consisted of canecutters, labourers, and fishermen. Class II involved less physical activity 
T A B L E VI

A COMPARISON OF OBSERVED AND PREDICTED VALUES OF FEV ${ }_{1}$ AND FVC IN GUYANESE SUBJECTS WITH CHRONIC BRONCHITIS

\begin{tabular}{|c|c|c|c|c|c|c|c|c|c|c|c|c|c|}
\hline \multirow{3}{*}{ Subjects } & \multirow{3}{*}{ No. } & \multicolumn{6}{|c|}{ FEV $_{1}$ (1. BTPS) } & \multicolumn{6}{|c|}{ FVC (1. BTPS) } \\
\hline & & \multicolumn{2}{|c|}{ Observed Values } & \multicolumn{2}{|c|}{ Predicted Values } & \multirow{2}{*}{$t$} & \multirow{2}{*}{$\mathbf{P}$} & \multicolumn{2}{|c|}{ Observed Values } & \multicolumn{2}{|c|}{ Predicted Values } & \multirow{2}{*}{$t$} & \multirow{2}{*}{$\mathbf{P}$} \\
\hline & & Mean & S.D. & Mean & R.S.D. & & & Mean & S.D. & Mean & R.S.D. & & \\
\hline African men & 3 & $2 \cdot 78$ & 0.45 & $2 \cdot 81$ & \multirow{2}{*}{$0 \cdot 37$} & $0 \cdot 19$ & N.S. & $3 \cdot 33$ & $3 \cdot 48$ & 0.64 & \multirow{2}{*}{0.46} & 0.67 & N.S. \\
\hline Indian men & 19 & $2 \cdot 02$ & 0.66 & $2 \cdot 50$ & & $3 \cdot 14$ & $<0.001$ & $2 \cdot 98$ & 0.46 & $3 \cdot 12$ & & $1 \cdot 26$ & N.S. \\
\hline African women & 5 & 1.99 & 0.60 & $2 \cdot 16$ & \multirow{2}{*}{$0 \cdot 31$} & 0.57 & N.S. & $2 \cdot 60$ & 0.44 & $2 \cdot 72$ & \multirow{2}{*}{0.38} & $0 \cdot 34$ & N.S. \\
\hline Indian women & 12 & $1 \cdot 55$ & $0 \cdot 36$ & $1 \cdot 74$ & & $2 \cdot 04$ & $<0.05$ & $2 \cdot 02$ & 0.40 & $2 \cdot 23$ & & $1 \cdot 56$ & N.S. \\
\hline
\end{tabular}

Predicted values were derived from healthy subjects as described by Miller et al. (in preparation).

R.S.D.= residual standard deviation about the multilinear regression.

and included painters, carpenters, masons, field foremen, and mechanics. Class III described more sedentary tasks such as those performed by clerks, tailors, shopkeepers, and teachers. Class I, class II, and class III comprised $57.9 \%, 30.4 \%$, and $11.7 \%$ of the Indian and $38.2 \%, 49.1 \%$, and $12.7 \%$ of the African men respectively (including pipe smokers and ex-smokers). A higher proportion of Africans were employed in trades such as carpentry and mechanics, whereas more Indians were cane-cutters or labourers. Almost all the women of both races described themselves as housewives but some also sold products in local markets and some, particularly Indian women, also worked in canefields.

The above classification of occupations revealed less with regard to respiratory symptoms than a classification into those men who worked as field labourers on sugar estates, carrying out tasks which included cutting cane, weeding, and maintaining irrigation canals, and those men involved in other occupations. Of the total of 214 Indian men, including pipe smokers and ex-smokers, 100 $(46.7 \%)$ worked as field labourers on estates compared with $30(18.2 \%)$ among all African men. Table VII shows the prevalence of chronic bronchitis in Indian men according to this type of occupation and to smoking habits. Fifteen (15.0\%) field labourers compared with 4 (3.5\%) other Indian men had chronic bronchitis $(\mathrm{P}<0.01)$. Thirteen of $51(25.5 \%)$ field labourers who smoked had chronic bronchitis compared with 4 of $47(8.1 \%)$ other Indian men who smoked $(\mathbf{P}<0.05)$. Among non-smokers and ex-smokers 2 in $49(4.1 \%)$ field workers had bronchitis but none in 67 other Indian non-smoking men. None of the three cases of chronic bronchitis in African men occurred among field labourers.

\section{DISCUSSION}

This study showed that chronic bronchitis was more prevalent and severe among the Indians of
Guyana than among the Africans. Morning cough, chronic cough, and morning phlegm were also more common in Indians.

The validity of the questionnaire method for assessing the relative prevalence of respiratory disease depends upon the questions having similar implications to both ethnic groups. This is likely because although there are some cultural differences between Indians and Africans in Guyana, there is much social intercourse between them, a common language is shared, and all responses were noted by the one observer. We believe that this intra-survey comparison of the prevalence of respiratory disease in the two ethnic groups is valid. Attempts to compare prevalence rates with those derived from surveys in Great Britain could be queried because the questions might not have the same meaning to Guyanese as to British people. Experience in both countries has shown that 'usually' is the main word in the questionnaire which is likely to lead to semantic difficulties, and in Guyana some respiratory symptoms may have been overestimated. Nevertheless the objective phrase 'for as much as three months each year' in questions 5 and 10 effectively prevents an overestimate of chronic cough and phlegm, that is of chronic bronchitis. That the prevalence of chronic bronchitis has not been overestimated is supported by the small number of African subjects (2.2\%) with the appropriate history and by the significant reduction in the $\mathrm{FEV}_{1}$ and presence of clinical signs of bronchitis among some of the Indians who gave a history of chronic bronchitis.

The peoples of India have been in the Caribbean for over 120 years. The acute labour shortage after 1838 in many areas of the Caribbean created by the emancipation of slaves forced the estate owners to look elsewhere and India proved the most fruitful source. Local attitudes towards Indian immigration, demands for labour, and the attitude of the government of India towards emigration to the various territories 
meant that the numbers of Indians introduced into the colonies varied greatly, and the recorded figures for the West Indies between 1844 and 1917, when the Viceroy of India banned the system, were British Guiana (now Guyana) 238,900 ; Trinidad, 143,900 ; Jamaica, 36,400 ; Grenada, 5,900 ; St. Lucia, 4,400 ; St. Vincent, 2,500 ; and St. Kitts, 300 (Roberts, 1957). These figures did not allow for migration back to India, which were recorded as 76,000 from British Guiana and 11,900 from Jamaica. The pattern of immigration reflected its aim-to secure labour for the sugar estates. Thus more than twice as many men as women were indentured, and most of the immigrant Indian population were between 10 and 30 years of age. Though quantity was satisfactory, quality was not: the profit-motivated agents in Madras and Calcutta enrolled many of the poor and infirm of Agra, Benares, Dacca, Delhi, Lucknow, Naypoor, and Patna, resulting in a high mortality rate among the immigrants (Dalton, 1855) and patients with open tuberculosis and leprosy reaching the West Indian ports. Most immigrants were Hindu and belonged to agricultural and menial castes (Smith, 1959). Today Indians comprise about $50 \%$ of the population of Guyana and Trinidad, and $3 \%$ of the Jamaican population.

The reason for the greater prevalence of chronic bronchitis in Indians than in Africans is not clear. The condition as it occurred in Indian men was obviously associated with smoking. For example, $17 \cdot 3 \%$ of Indian men who smoked gave a history of chronic bronchitis compared to $2.4 \%$ who had never smoked. In contrast, only $2.4 \%$ of African male smokers had chronic bronchitis, a prevalence little different from that among non-smokers $(1.8 \%)$. The higher prevalence of chronic bronchitis among Indian than among African smokers cannot be explained by differences in the type of cigarette used as both ethnic groups smoked manufactured cigarettes of the same brands in the customary manner. Although in the analysis all cigarette smokers were grouped together, there was no evidence that Indians were heavier smokers than Africans, for $23.5 \%$ of Indian smokers said they smoked more than $15 \mathrm{~g}$ of cigarette tobacco per day compared with $21.2 \%$ of African smokers (Table I). The possibility that Indians inhaled tobacco smoke more than Africans was not investigated because many of the subjects did not understand the correct meaning of the word. We think it unlikely that differences in inhalation would account for the greater prevalence of chronic bronchitis in Indians.

Occupational differences were considered. As shown in Table VII the prevalence of chronic bronchitis was higher in Indian men working as labourers on sugar estates than in other Indian men, a relationship which was independent of smoking habits. However, 30 African men also worked as field labourers and none suffered from chronic bronchitis. It would appear that Indians were not only more susceptible to the effects of smoking than Africans, but also to the conditions associated with field labour which may lead to chronic bronchitis. What these conditions might be remains a matter of speculation and, in the absence of any obvious explanation, should be confirmed and clarified by further investigation.

This survey suggests that Indians may be more susceptible to chronic bronchitis than Africans and therefore supports the impression which seems to have been present in the Caribbean area since the end of the nineteenth century that certain respiratory diseases are more common in Indians. Daniels (1894) wrote that, surprisingly, lobar pneumonia was a serious problem in British Guiana, particularly among the Indians, but was unable to offer an explanation. MacQuaide (1908) stated that lobar pneumonia was still on the increase at that time and Rowland (1913) noted that, unlike in England, it was mainly a rural problem in British Guiana. Both writers agreed with Daniels that the condition was more prevalent in the Indian than the African subject, in contrast to the greater prevalence of a history of

T A B LE VII

PREVALENCE OF CHRONIC BRONCHITIS IN INDIAN MEN ACCORDING TO SMOKING HABITS AND OCCUPATION

\begin{tabular}{|c|c|c|c|c|c|c|c|c|}
\hline & \multicolumn{3}{|c|}{ Smokers } & \multicolumn{3}{|c|}{ Non-smokers and Ex-smokers } & \multirow[b]{2}{*}{$\begin{array}{c}\text { Total } \\
\text { Subjects }\end{array}$} & \multirow{2}{*}{$\begin{array}{c}\% \text { with } \\
\text { Chronic } \\
\text { Bronchitis }\end{array}$} \\
\hline & $\begin{array}{l}\text { No. of } \\
\text { Subjects }\end{array}$ & $\begin{array}{l}\text { Chronic } \\
\text { Bronchitis }\end{array}$ & $\begin{array}{l}\% \text { with } \\
\text { Chronic } \\
\text { Bronchitis }\end{array}$ & $\begin{array}{l}\text { No. of } \\
\text { Subjects }\end{array}$ & $\begin{array}{l}\text { Chronic } \\
\text { Bronchitis }\end{array}$ & $\begin{array}{l}\% \text { with } \\
\text { Chronic } \\
\text { Bronchitis }\end{array}$ & & \\
\hline $\begin{array}{l}\text { Field labourers in sugar estates } \\
\text { Other subjects }\end{array}$ & $\begin{array}{l}51 \\
47\end{array}$ & $\begin{array}{r}13 \\
4\end{array}$ & $\begin{array}{r}25 \cdot 5 \\
8 \cdot 1\end{array}$ & $\begin{array}{l}49 \\
67\end{array}$ & $\underset{\text { nil }}{2}$ & $\begin{array}{l}4 \cdot 1 \\
\text { nil }\end{array}$ & $\begin{array}{l}100 \\
114\end{array}$ & $\begin{array}{r}15 \cdot 0 \\
3 \cdot 5\end{array}$ \\
\hline Total & 98 & 17 & $17 \cdot 3$ & 116 & 2 & $1 \cdot 7$ & 214 & $8 \cdot 9$ \\
\hline
\end{tabular}


pneumonia in Africans in the present survey. At least part of what was diagnosed as lobar pneumonia appears to have been either an acute exacerbation of a chronic infective process or some other lung disease, for MacQuaide stated that delayed resolution of signs or complete failure of resolution were frequent and that pulmonary fibrosis was a complication.

Later the recognition of a distinct form of diffuse pulmonary fibrosis which predominated among the Indians reinforced the impression in Guyana that people of this race were more likely to develop lung disease than the Africans. Pulmonary fibrosis in Guyana has now been shown to be a lipoid pneumonia caused by smoking an unusual form of tobacco flavoured with petroleum oil called blackfat, a habit virtually confined to the Indian population. As blackfat tobacco has been used in Guyana since 1870 some of the lung disease prevalent at the turn of the century may have been due to pulmonary fibrosis (Miller et al., in preparation).

Tropical eosinophilia is another disease with respiratory symptoms which is recognized as being more common among the Indian than the African population in Guyana (Herlinger, 1963). Symptoms are transitory and are characterized by a low-grade pyrexia, breathlessness, wheezing, and a dry cough. During attacks chest radiography shows diminished translucency, increased striation, and reticulation of the lung fields. In his analysis of $\mathbf{3 5 0}$ cases in Guyana, Herlinger found that $65 \%$ were male, $43 \%$ were under 10 years of age, and $73 \%$ were Indians, who accounted for only $50.7 \%$ of the population at the time. The greater prevalence of respiratory symptoms among Guyanese Indians in the survey is unlikely to be due to tropical eosinophilia for several reasons. The cardinal symptoms in tropical eosinophilia are breathlessness and wheezing but no significant differences in the prevalence of these symptoms were seen between ethnic groups or between smokers and non-smokers. A history of asthma, which might be confused with tropical eosinophilia also, occurred more or less evenly in the groups. Although the disease can produce a cough that persists for appreciable periods of time, chronic phlegm and a reduction in the $F_{1}$ between acute episodes are not recognized features. Tropical eosinophilia produces primarily a patchy inflammatory reaction in the pulmonary interstitial tissue with associated granulomatous lesions. Although the peribronchial tissues are infiltrated with eosinophilic leucocytes and the bronchial lumina contain exudates, the main inflammatory reaction is away from the bronchial tree and is unlikely to give rise to chronic bronchitis (Danaraj, Pacheco, Shanmugaratnam, and Beaver, 1966).

In contrast to other respiratory conditions, tuberculosis has been more of a problem in the African than in the Indian in the Caribbean. Although almost certainly introduced many times during the eighteenth and nineteenth centuries, tuberculosis did not establish itself in the Caribbean area until after 1850 (Godfrey, 1912; Gillette, 1960). Migration of the former slaves from the estates into the shanty conditions of the new villages, and freedom to come into contact with infected persons probably soon made tuberculosis a prominent cause of death. In Guyana the urbanized African suffered more severely than the Indian on the estates; thus in 1911 the tuberculosis death rate in the towns was $2 \cdot 0 / 1,000$, compared with $0.9 / 1,000$ on the estates (Godfrey, 1912). The disease has declined over the past 60 years, but Sneath (1943) recorded that prior to 1940 the tuberculosis mortality rate of Africans in Guyana was considerably in excess of that for Indians. Thomas (1960) visualized resistance to tuberculosis in the Caribbean as increasing progressively from a low level in the Amerindian, to the African then to the Indian, and on to the high resistance of the Chinese and European. Many physicians believe that chronic bronchitis is more common among Indians than among other ethnic groups in the Caribbean but the only previous study of which we are aware is that of Miller and Hayes (1968) who found that $16 \%$ of patients with chronic bronchitis and emphysema in a Jamaican hospital were Indian although this ethnic group comprises only $3 \%$ of the total Jamaican population.

The annual reports of the Registrar General (1957-61) support the evidence that, with the exception of tuberculosis, Indians are more susceptible to respiratory disease than are other ethnic groups in Guyana. Table VIII presents the mean

T A B L E V I I I

ANNUAL MORTALITY RATE PER 10,000 POPULATION AGED OVER 45 YEARS IN GUYANA, 1957-61

\begin{tabular}{l|r|r}
\hline & Indians & Other Race : \\
\hline All causes & 338.0 & 311.0 \\
Asthma & $10 \cdot 8$ & 1.8 \\
Tuberculosis of respiratory system & 3.5 & 4.4 \\
Chronic bronchitis & 20.7 & 6.1 \\
Pneumonias & 11.5 & 11.1 \\
Other diseases of respiratory system & 7.4 & 6.8 \\
All diseases of respiratory system & 53.9 & 30.2 \\
\hline
\end{tabular}


annual death rates per 10,000 population over 45 years of age from 1957 to 1961 by various causes.

In the Indian community the mortality rate per 10,000 from all causes was $338 \cdot 0$ with a rate from all respiratory disease of 53.9. In other races comparable rates were 311.0 and 30.2 . About one in six deaths in Indians was recorded as being due to respiratory causes compared to about one in 10 among other races. Asthma and chronic bronchitis were much more important causes of death in Indians with mortality rates of 10.8 and 20.7 respectively in Indians compared to 1.8 and 6.1 in other races. Death rates from tuberculosis, pneumonia, and other diseases of the respiratory system differed little between the ethnic groups. Some of the excess mortality in Indians attributed to asthma and chronic bronchitis may, in fact, have been due to pulmonary fibrosis. It must be emphasized that death certification is not accurate in Guyana but nevertheless the data suggest that Indians may be more liable than other ethnic groups to bronchial disease.

Ethnic differences in disease patterns due to genetic rather than environmental reasons are not rare. In Guyana, for example, Indians suffer much less from elephantiasis than do Africans although their exposure to Wuchereria bancrofti has been, as far as can be ascertained, similar. In the survey reported here $12.0 \%$ of African women had elephantiasis of the legs compared with $1.8 \%$ of Indian women. Africans in Guyana are taller and more muscular than Indians (Ashcroft et al., 1969) and their ventilatory capacities are greater even after standardizing for height and age (Miller $e t$ $a l$., in preparation). These differences appear to be inherited and it seems likely that different responses to adverse environmental influences may, in part, also be inherited.

If there is a real difference in ethnic susceptibility to chronic bronchitis then a similar situation to that found in the Caribbean may be present in other multi-racial communities in which Indians form a distinct group such as Fiji and Mauritius. No reference to this topic has as yet been traced from these areas.

The authors thank Dr. H. M. S. G. Beadnell, Lusignan Hospital, Guyana Sugar Producers Association, Guyana, Dr. W. E. Miall, Dr. J. E. Cotes, Dr. T. Poon-King, and Mr. A. V. Swan for their assistance and advice.

\section{REFERENCES}

Ashcroft, M. T., Beadnell, H. M. S. G., Bell, R., and Miller, G. J. (1970). Characteristics relevant to cardiovascular disease among adults of African and Indian origin in Guyana. Bull. Wld Hlth Org., 42, 205.

__ Miller, G. J., and Bell, R. (1969). Anthropometric measurements of Guyanese adults of African and East Indian racial origins. Trop. geogr. Med., 21, 169.

Collins, M. M., McDermott, M., and McDermott, T. J. (1964). Bellows spirometer and transistor timer for the measurement of forced expiratory volume and vital capacity. J. Physiol. (Lond.), 172, 39P.

Dalton, H. G. (1855). The History of British Guiana, vol. 1, p. 467. Longman, Brown, Green, and Longmans, London.

Danaraj, T. J., Pacheco, G., Shanmugaratnam, K., and Beaver, P. C. (1966). The etiology and pathology of eosinophilic lung (tropical eosinophilia). Amer. J. trop. Med. Hyg., 15, 183.

Daniels, C. W. (1894). Notes on a series of post-mortems made in the Public Hospital, Georgetown, from 1st April to 31st December, 1893. Brit. Guiana med. Annual, $6,79$.

Gillette, H. P. S. (1960). Comments on Dr. Thomas's report of the chest service for the Federation of the West Indies. Carib. med.J., 22, 16.

Godfrey, J. E. (1912). Tuberculosis in British Guiana. Brit. Guiana med. Annual, 19, 65.

Herlinger, H. (1963). Pulmonary changes in tropical eosinophilia. Brit. J. Radiol., 36, 889.

MacQuaide, T. B. (1908). Lobar pneumonia. Brit. Guiana med. Annual, 16, 92.

Medical Research Council's Committee on the Aetiology of Chronic Bronchitis (1965). Definition and classication of chronic bronchitis for clinical and epidemiological purposes. Lancet, 1, 775.

Miller, G. J., Ashcroft, M. T., Swan, A. V., and Beadnell, H. M. S. G. (1971). Ethnic variation in forced expiratory volume and forced vital capacity of African and Indian adults in Guyana. (In press).

—_ Beadnell, H. M. S. G., and Ashcroft, M. T. (1968). Diffuse pulmonary fibrosis and blackfat-tobacco smoking in Guyana. Lancet, 2, 259.

- and Hayes, J. A. (1968). Unpublished data.

Registrar General (1957-61). Annual reports of British Guiana, Georgetown.

Roberts, G. W. (1957). The Population of Jamaica. p. 110. University Press, Cambridge.

Rowland, E. D. (1913). Pneumonia in British Guiana. Brit. Guiana med. Annual, $20,38$.

Smith, R. T. (1959). Some social characteristics of Indian immigrants to British Guiana. Population Studies, 13, 34.

Sneath, P. A. T. (1943). Contemporary facts on the incidence of tuberculosis in British Guiana. Brit. Guiana med. Annual, 27, 32.

Thomas, J. H. (1960). Respiratory tuberculosis in the Caribbean region. Carib. med.J., 22, 20. 